\title{
Money, Debt and Economic Activity
}

\author{
R. W. Hafer
}

\section{$\mathbf{T}$} HE Federal Open Market Committee (FOMC) decided in October 1982 that, at least for the immediate future, less importance would be attached to movem ments in the narrowly defined monetary aggregate (M1) in establishing monetary policy. 'This departure from previous policy was motivated primarily by increasing expectations that the introduction of SuperNOW accounts would distort M1's usefuness as a rellable policy guide.

The notion that M1 may not be appropriate as the intermediate target measure is not confined to the period since 1982. Some economists long have argued that policy should not be based on a single variable, but on a variety of "informational" variables. If one target variable displays "abnomal" behavior, other target variables can be consulted for similar irregularities. Rather than basing policy on a target variable gone astray, policymakers can thus evaluate a diverse set of information and assign the proper weight to each intermediate target variable. ${ }^{1}$

R. W. Hafer is a senior economist at the Federal Reserve Bank of St. Louis. Larry J. DiMariano provided research assistance.

'Kareken, Muench and Wallace (1973), for example, conclude that the monetary policymakers should use all the information variables to which they have access. To some extent, knowledge of economic activity does play an important role in the FOMC's decision calculus. One need only read the "Record" of the FOMC meetings to see the extent to which economic conditions, such as real economic activity, price developments and recent changes in interest rates, influence monetary policy decisions. On the question of using several intermediate targets, Kane (1982), p. 204, draws the opposite conclusion: "I doubt very much that systems that employ a multiplicity of intermediate targets constitute efficient ways to organize decisions about monetary policy."
Suspicion of recent distortions in M1 has prompted some economists to suggest that the Federal Reserve target a broad debt measure. ${ }^{2}$ Their argument against too heavy a reliance on monetary measures is that such measures capture only the asset side of the nonfinancial sector's financial balance sheet; information from the liability side is being overlooked. Consequenty, charting the path of a broad debt measure in addition to a monetary aggregate, they argue, will provide policymakers with information not revealed solely by money growth. Partially in response to these arguments, the FOMC at its February 1983 meeting established a monitoring range for the growth of total domestic nonfinancial debt.

This paper investigates the usefunness of adding this debt measure to the collection of targets already used to decide the direction of monetary policy. Because any variable used as an intemediate target should be closely related to the goal of monetary policy, we will first compare how well the growth rates of $\mathrm{M} 1$ and debt explain the behavior of GN" growth in the past two decades. ${ }^{*}$ We also will compare each measure's ability

\footnotetext{
${ }^{2}$ This position has been argued by Benjamin Friedman in a series of papers (1981, 1982, 1983a). See also Kopcke (1983) and Morris (1982, 1983) for further arguments in favor of using the broad debt measure.

${ }^{3}$ The analysis in this paper draws on Hafer (1984a), where the issue is investigated in greater detal using a variety of statistical tests.

${ }^{4}$ During the past 20 years, numerous papers have investigated this link between different monetary measures and GNP: see, among others, Friedman and Meiselman (1963), Hamburger (1970), Carlson and Hein (1980), Hafer (1981), and Judd and Motley (1983).
}

Another feature of an intermediate target, one that is not deat with in this paper, is that it should be controllable by the policymaker. In 
to forecast GNP growth during the 1982-83 period. Forecasts of GNP using an M1 meastre that abstracts from recent financial innovations that may have distorted M1 growth (here called adjusted M1 also are reported. The evidence reveals that there is insufficient evidence to support the usefulness of the debt measure relative to two measures of narrowly defined money as a potential intermediate target for monetary policy. $^{3}$

\section{TOTAL DOMESTIC NONFINANCLAL DEBT}

Total domestic nonfinancial debt, put simply, is a measure of the credit market debt owed by domestic nonfinancial sectors of the U.S. economy. As the definition suggests, the measure excludes debt owed by financial institutions, including U.S. governmentsponsored credit agencies, federally related mortgage pools and private financial institutions. It also excludes Irade debt, loans for the purpose of carrying securities and funds rased from equity sources. On the other hand, the debt measure includes debt securities, mortgages, bank loans, commercial paper, consumer credit and government loans owed by nonfinancial sectors.

Table 1 presents a summary of the composition of this debt measure by major sector as of W/1983. In that quarter, total domestic nonfinancial debt stood at $\$ 5,218.96$ billion. Of this amount, debt owed by the household sector and nonfinancial businesses accounted for 70 percent of the total. The govemment sector owes the remainder, with the U.S. government

other words, changes in the "tools" of monetary policy, that is, changes in open market operations, reserve requirements and the like, should have reliable consequences on the intermediate target. Thus, although a measure may be closely related to the goal variable, this is of fittle solace if it is uncontrollable. Some evidence on the controllability of debt with respect to $\mathrm{M} 1$ is presented in Friedman (1983a) and Kopcke. Kopcke's evidence, based on one-, two- and three-month-ahead forecasts of an $M 1$ and debt multiplier, suggests that the forecast errors of the debt multiplier are not offsetting as they are for the M1 multiptier. For example, the average error for the one-month-ahead forecasts for the period November 1979 through June 1982 are 0.06 percent for $M 1$ and 0.23 percent for debt. When two- and three-month forecast horizons are used, the debt multplier's average forecast error is at least twice that for M1. Although the mean absolute value of the wo series' forecast errors are similar, the relative biasedness of the debt multiplier's forecasts could, if used for policy, produce incorrect signals. This is especially true because, as Kopcke notes, the debt data are available only with a lag, while the M1 data are calculated on a weekly basis. Moreover, there appear to be large revisions in the debt data unmatched by any of the relevant monetary measures.

${ }^{5}$ A sirtilar conclusion is reached by Porter and Offenbacher (1983). and Davidson and Hafer (1983).

\section{Table 1 \\ Total Domestic Nontinancial Debt: IV/1983 (billons of dollars)}

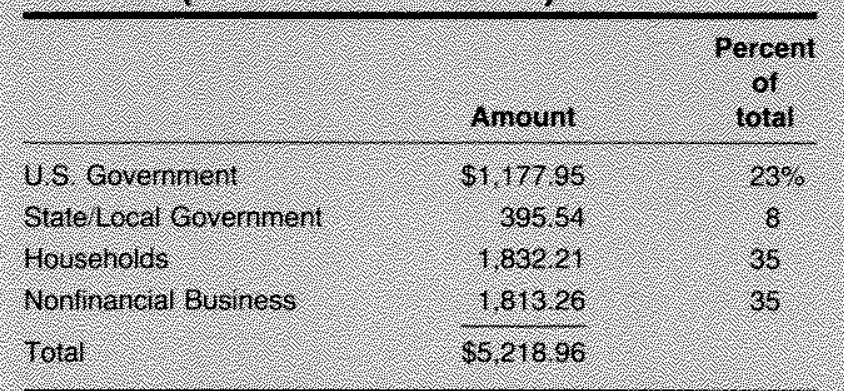

NonE 1 otal does not equal 100 percert due to rounding.

sector's share being about three times that of state and local governments.

As shown in chant 1 , the relative shares of the total debt measure owed by the various sectors have changed over time. For example, in 1960, the share of total debt accounted for by households and nonfinancial businesses was about 30 percent and 27 percent, respectively. By 1983, their shares each had risen to about 35 percent of the total. The proportion of debt owed by state and local govermments has remained relatively unchanged during the past 20 years, decining from about 10 percent in 1960 to around 8 percent in 1983.

During the same period, however, the percentage of total debt accounted for by the U.S. government has varied considerably. From 33 percent in 1960, the U.S. government's share dropped to about 17 percent in 1974. Since then, it has increased to nearly 24 percent.

\section{WHICH EXPLAINS ECONOMIC ACTIVTTY BETTER: M1 OR DERT?}

Those who advocate the use of a debt measure as a target variable have presented evidence indicating that the level of debt relative to the level of GNP (debt velocity) has been relatively constant over the past few decades, in contrast to the M1-GNP relationship. They argue that the stable relationship between debt and GNP can be exploited for policy decisions. If the goal of monetary policy is to achieve some desired growth of

\footnotetext{
'See, for example, the evidence presented in Friedman (1981, 1983a,b) and Kopcke.
} 
Chart I

\section{Composition of Domestic Nonfinancial Debt}

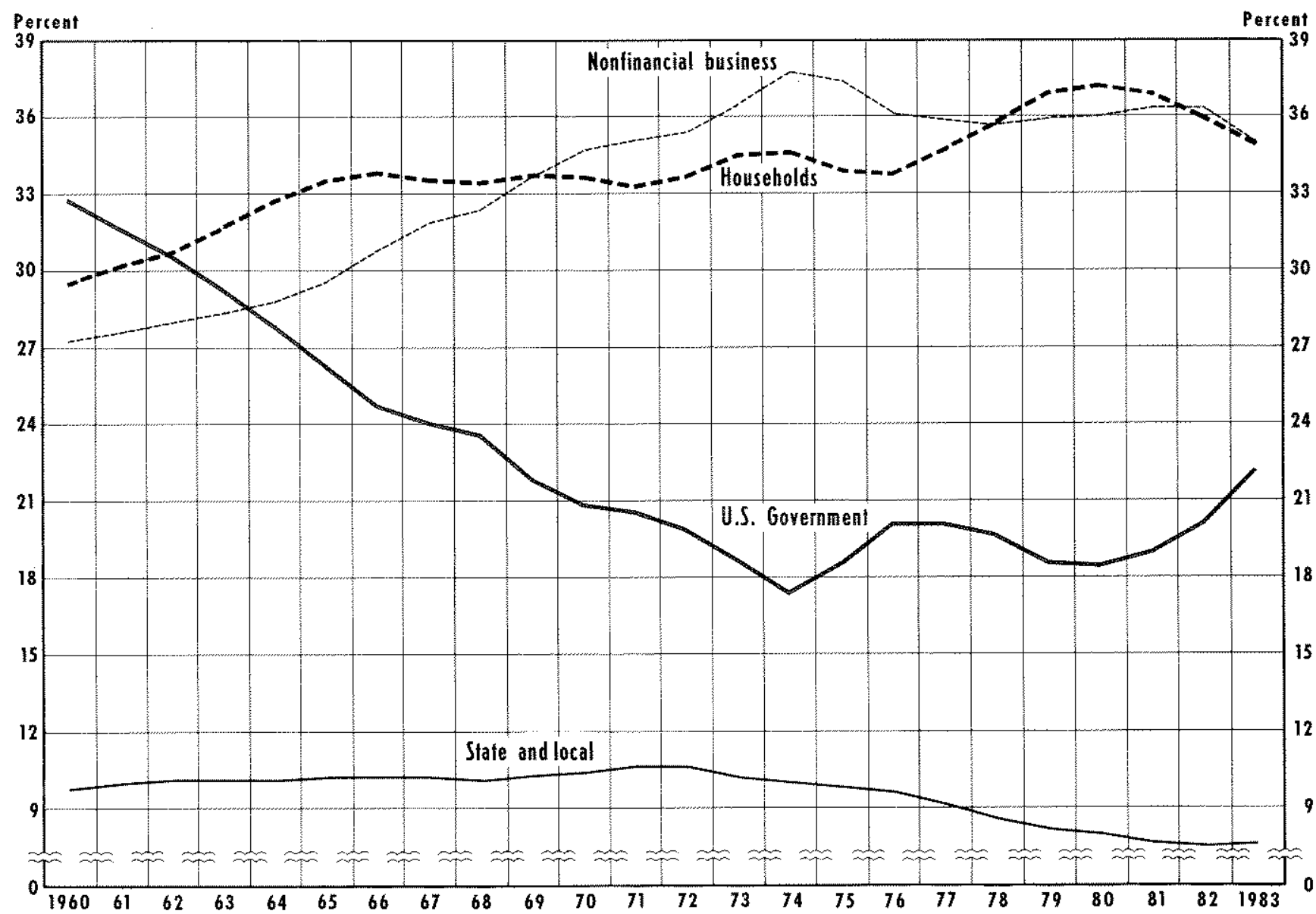

nominal GNP through the use of intermediate growth targets, however, the salient question is how well do the growth of $\mathrm{M} 1$ and debt explain variations in the growth of GNP? This issue is critically important in the selection of a viable intermediate target measure.

To investigate this issue, a variant of the St. Louis reduced-form GNP equation is used. This equation

${ }^{7}$ The basic equation is described in Tatom (1981). The model is written as:

$$
\begin{aligned}
G \dot{N P} & =\alpha_{0}+\beta, \sum_{i=0}^{M} m_{i} \dot{M}_{t-i}+\beta_{2} \sum_{j=0}^{N} g_{i} \dot{G}_{t-j} \\
& +\beta_{3} \sum_{k=0}^{Q} p e_{k} \dot{P}_{t-k}^{e}+\beta_{4} S_{t}+\varepsilon_{t}
\end{aligned}
$$

where $M$ represents money, $G$ is high-employment federat expenditures, $P^{e}$ is the relative price of energy and $S$ is the strike variable. The dots above each measure denote rates of change, measured here as logarithmic differences. relates the growth of nominal GNP to a measure of monetay actions, fiscal actions, changes in the relative price of energy and a measure to account for lost production due to labor strikes. By substituting the debt measure for $\mathrm{M} 1$ in the equation, we are able to compare the two measures' ability to explain movements in GNP growth.

Equations of the form described above were estimated using seasonally adjusted, quarterly data for the period 1/1960-IV/1981. This sample period is used because it predates the 1982-83 period in which many believe M1's usefulness as an intermediate target declined considerably. Thus, our sample period enables us to compare each measure's relative capabilities in explaining GNP during an "untroubled" time. Also, these estimates can be used to forecast GNP growth to see whether the debt measure better predicts GNP during the perplexing $1982-83$ period. Summary results of the estimations are presented in table 2. 


\section{Table 2}

Regression Results for GNP Equations I/1960-IV/1981

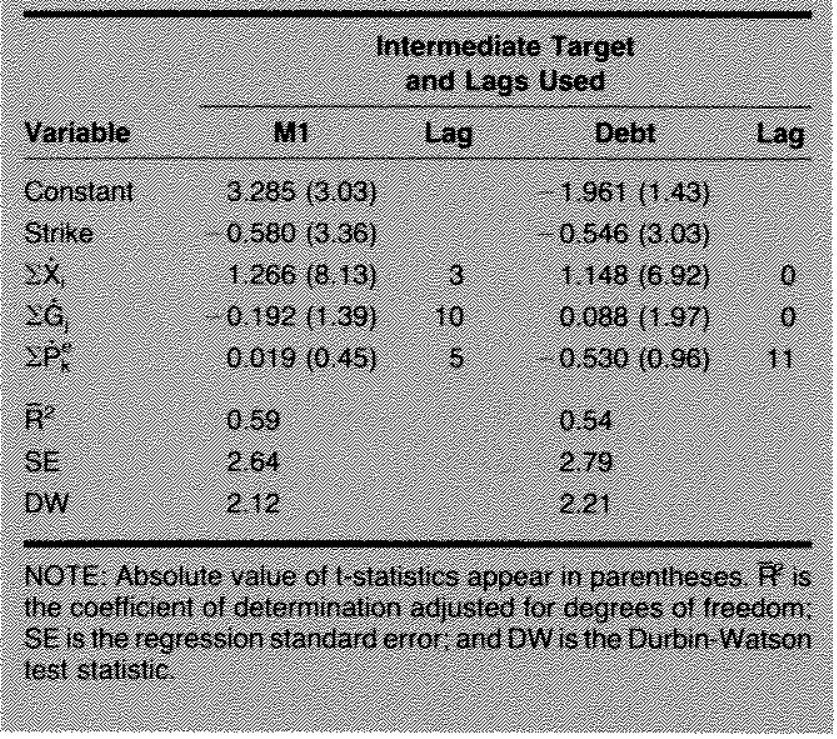

Turning first to the results based on M1, we find that the equation accounts for about 60 percent of the variation in GNP growth. The regression results indicate that a 1 percentage point increase in M1 growth produces a 1.3 percentage point increase in the growth of GNP after three quarters. Although this estimated "long-run" effect is somewhat larger than the usual value of unity, a test of the hypothesis that this estimate does not differ statistically from one could not be rejected at a standard 5 percent level of significance. ${ }^{9}$ The familiar result that fiscal actions exert no lasting effect on GNP growth is revealed in the estimated coefficient: the summed coefficient's value of -0.19 is not statistically different from zero at the 5 percent level. ${ }^{10}$ Finally, the results indicate that the long-run effect of a change in the relative price of energy is zero, as theory predicts, and that days lost due to work stoppages have a significant, negative impact on the growth of GNP.

\footnotetext{
${ }^{8}$ The equation is estimated using ordinary least squares. The lag lengths $M, N$ and $Q$ in footnote 7 were determined using several statistical tests: Mallows Cp. Akaike's Final Prediction Erro: criteria and the Pagano-Hartiey procedure. Where lag lengths selected by the procedures differed, F-tests were used to pick the best lag for each variable. For further discussion of these lag length selection procedures as they apply to this type of specification, see Batten and Thornton (1984)

The calculated t-statistic is 1.71 .

${ }^{10}$ Evidence on the long-run insignificance of fiscal actions on GNP is investigated more fully in Hafer (1982).
}

The second set of regression results reported in table 2 replaces $M 1$ growth with the growth of total domestic nonfinancial debt. It is interesting to note that the lag-length selection procedures chose only contemporaneous values of debt growth. The estimated coefficient on this term is 1.15 , indicating that a 1 percentage point increase in the growth of debt translates into a 1.15 percentage point increase in nominal GNP growth in the same quarter. ${ }^{11}$ Although we again find that the cumulative effect of the change in the relative price of energy is not statistically different from zero $t=0.96)$, the result for fiscal actions suggests a marginally significant contemporaneous effect $(t=1.97)$. This effect is, however, quite small in magnitude: a 1 percentage point increase in the growth of government expenditures yields only a 0.09 percentage point change in GNP growth. Moreover, because of the contemporaneous nature of this result, it is difficult to translate this finding into a meaningful long-run outcome.

A comparison of each equation's overall explanatory power indicates that M1 outperforms debt in explaining variations in GNP growth. The $\overline{\mathbf{R}}^{2}$ of the estimated equation using $M 1(0.59)$ is about 10 percent higher than that using debt (0.54). This difference, however, is not large and has led some to argue that this relative closeness does not preclude the usefulness of debt as an additional policy variable. As Benjamin Friedman has stated the case, "the evidence does not warrant including the money market but excluding the credit market on the grounds of the closeness, or lack thereof, of the observed empirical relationships." 12

Of course, a comparison of relative explanatory power of GNP equations using M1 or debt may not provide an adequate test of their relative abilities to explain GNP. A more appropriate test would be to compare their marginal informational content. In other words, after we have accounted for the effects of M1 (debt) growth on GNP, is there any statistically significant, additional explanatory power gained by adding debt (M1) growth to the equation?

To test this notion, a contemporaneous debt growth term was added to the M1 equation shown in table 2. This expanded equation then was compared statistically to the previously estimated M1 equation. The result reveals that adding debt growth does not en-

\footnotetext{
${ }^{11}$ Testing the hypothesis that the estimated coefficient on debt equals unity yields a $t$-statistic of 0.89 . Thus, we cannot reject the nutl hypothesis that the coefficient equals one.

${ }^{12}$ Friedman (1983b), p. 186.
} 
hance M1 growth in explaining the growth of GNP: the calculated $F-$ statistic was 1.72 , far below the 5 percent critical value of 3.99 . 'The reverse test, that of adding a contemporaneous and three lagged terms of M1 to the debt equation in table 2 , also was performed. The calculated F-statistic was 3.33 , large enough to exceed the 5 percent critical value of 2.50 .

These results demonstrate that the apparent closeness in explanatory power between reduced-form GNP equations using $\mathrm{M} 1$ or debt derives from the close relationship between these two measures; that is, debt growth reflects the behavior of M1 growth when the latter is absent from the estimated equation. ${ }^{13}$ Once the effects of M1 growth are estimated directly, the debt growth measure is redundant; it contains no additional statistically useful information.

\section{M1 AND DEBT: THE 1982-83 EXPERIENCE}

Some have argued that there has been a dramatic breakdown in the money-GNP link during the last two years and, therefore, the use of another, nonmonetary intermediate target is required. Presumably, the debt measure would not be subject to the same changes in its relationships with GNP; consequently, it would be a more reliable intermediate target. To test this presumption, we compare the behavior of M1 and debt velocity growth rates since the recession trough (IV) 1982) with historical patterns to see how well the equations estimated earlier forecast movements in GNP during the 1982-83 period.

\section{Velocity Behavior of M1 and Debt during the Recovery}

The recent behavior of velocity growth has been cited as an illustration of the supposed deterionation in the money-GNP link." To put velocity behavior in a historical perspective, the quatterly growth rates of $\mathrm{M} 1$ velocity in the trough quarter and the following foum quarters for the most recent and four previous recessions are listed in the upper panel of table 3 .

\footnotetext{
${ }^{13}$ This result gains further credence if one examines the causal relationship betweer $M 1$ growth and debt growth. As reported in Hafer (1984a) using a sightly different sample period, the evidence overwheimingly indicates that $M 1$ growh Grangef-causes debt growth. Also, evidence based on the lag length selection procedures indicates that, when $M 1$ and debt growh are included in the GNP equation, no deb terms are significant.

${ }^{14}$ Analyses of the recent behavior of velocity include, among others,
} Hein and Veugelers (\$983), Judd (1983) and Tatom (1983).
The most recent behavior of $\mathrm{M} 1$ velocity $\{\mathrm{T} / 1982)$ clearly has been slower than the "average" recovery phase. The negative growth of velocity during the trough quarter and one quarter into the recovery are unmatched in the sample. The behavior of M1 velocity during the next three quarters also diverge from the average. Moreover, the avelage growth of M1 velocity during the four quarters after the trough was 5.36 percent during the previous four recoveries. In contrast, M1 velocity growth since IV/1982 has averaged only a 0.45 percent rate of growth.

The behavior of debt velocity during the current recovery, reported in the middle panel of table 3 , also appears unlike its average post-trough period. Following the IV/1982 trough, debt velocity growth, like M1 velocity growth, was considerably below the average rate for several quarters. For example, the average ate of growth for debt velocity in the year following the trough was 2.06 percent. During the first year of the recent expansion, debt velocity growth averaged a negative 0.27 percent rate.

The most recent experience is not without historical comparison, however. The recovery following the 1970 recession, for example, reveals a substantial decline in debt velocity well into the expansion phase of the cycle. Thus, the debt measure does not seem to be a relatively more stable guide to GNP behavion than M1 during the past few years.

\section{Velocity Using an Adjusted M1 Measure}

Several recent studies have suggested that the problem with the M1 velocity behavior during the recent recovery is that "effective" money growth - growth that represents increases in transaction-oriented hold. ings - has been overstated because of financial innovations like the Super-NOW accounts introduced in January $1983^{15}$ One approach to investigate this con" cern is to use an adjusted M1 measure that excludes accounts with the dual characteristics of transaction and savings accounts. ${ }^{16}$

When this adjusted $M 1$ measure is used to calculate velocity growth during the recent recovery, the results are considerably different. For example, as shown in the lower panet of table 3 , adjusted M1 velocity growth

\footnotetext{
${ }^{15}$ See, for example, Judd and McElhattan (1983) and Hafer (1984b).

${ }^{16}$ The approach taken here follows Hafer (1984b); that is, the adjusted V1 measure omits interest-bearing checkable deposits. This approach admittedly overstates the savings nature of interestbearing checkable deposits relative to the more sophisticated techniques of, say. Spindt (1984).
} 


\section{Table 3 \\ Velocity Growth During Recovery}

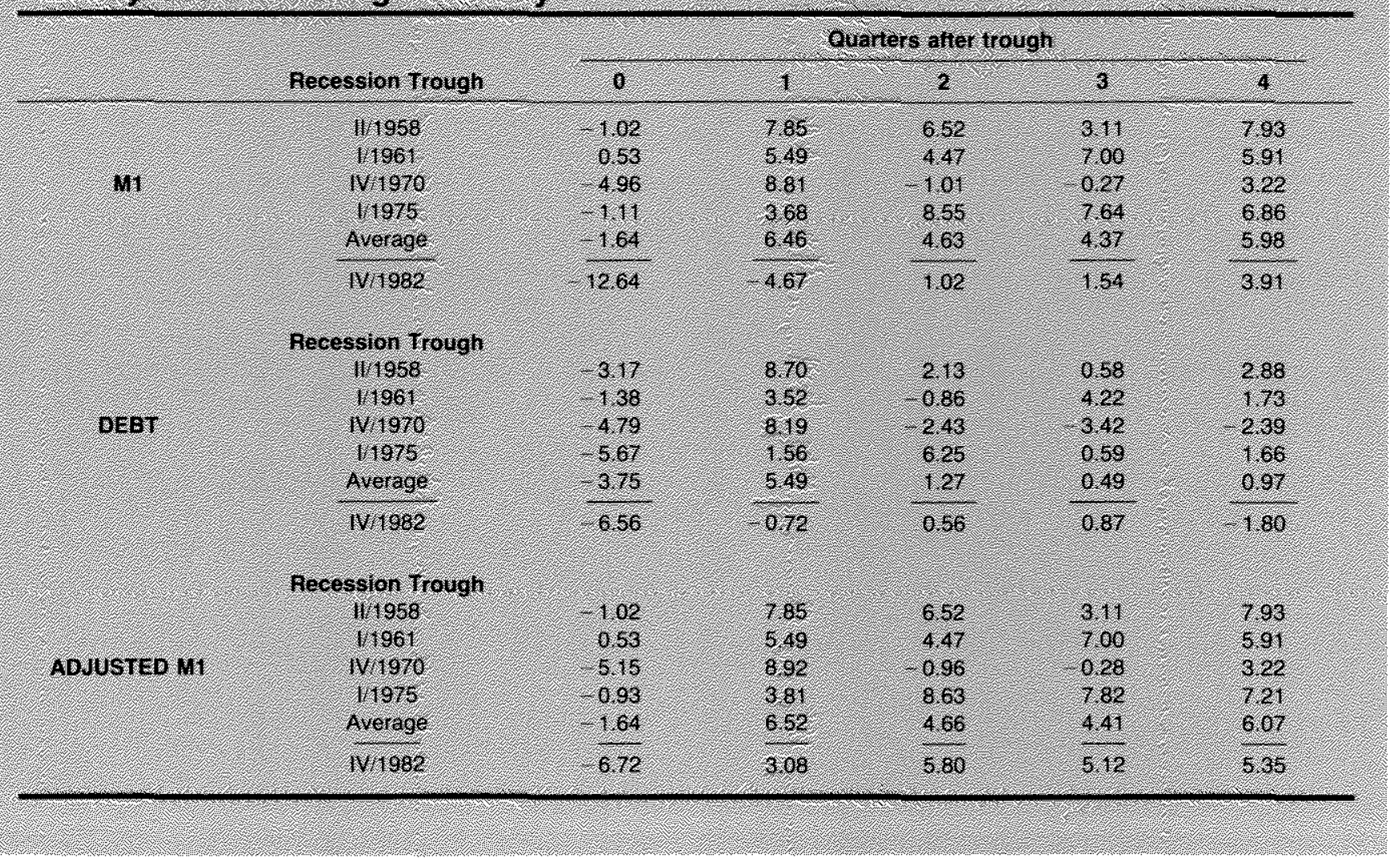

in the $\Gamma / 1982$ trough quarter is -6.7 percent, com pared with -12.6 percent using M1. The average ad justed M1 velocity growth rate in provious troughs is -1.64 percent. During the four quarters after IV/1982, the growth of adjusted M1 velocity averages 4.84 per- $^{-}$ cent per quarter, compared with the 5.42 percent average quarterly tate from previous recovery phases. In contrast, the growth rate of M1. velocity as currently defined averages only 0.45 percent during the four quarters after the W/1982 trough. Thus, relative movements in debt velocity during the post-IV/1982 recovery suggest that the behavior of an M1 velocity measure that reduces the influence of financial innovations dzr ing the post-1V/1982 period is much closer to previous norms.

\section{Forecasting GNP}

A common technique used to assess the viability of alternative target variables is to examine the accuracy of out-of-sample forecasts of economic activity. Based on the coefficient estimates underlying the results reported in table 2, quarterly forecasts of GNP growth for the 1982-83 period were made using the actual growth rates of $\mathrm{M} 1$ and debt, as well as the other explanatory variables. The out-of-sample forecast errors derived from the $\mathrm{M} 1$ and debt equations along with actual GNP growth are reported in table $4 .^{17}$

The forecast errors from the M1 equation indicate that M1 continually overpredicted GNP growth throughout $1982-83$. The mean error is a negative 5.49 percent with the largest quarterly errors appearing in L/1982, IIL/1982, $\mathrm{NV} / 1982$ and $\mathrm{L} / 1983{ }^{18}$ It is interesting to note that these latter errors occur about the time when discussions about the effects of financial innovations on M1 suggest that M1 growth may be overstated. Moreover, the root-mean-squared error $(\mathrm{RMSE})$ is 5.93 .

\footnotetext{
${ }^{17}$ The errors reported are actual minus predicted GNP growth.

${ }^{18}$ These errors exceed two standard errors from the regression equation $(S E=2.64)$.
} 


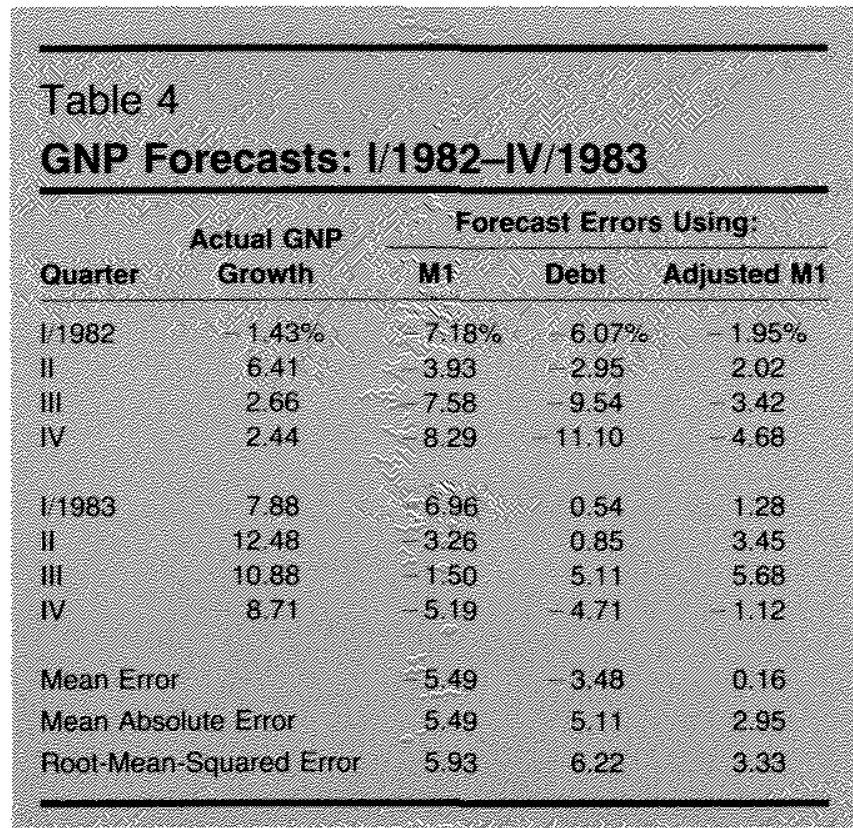

a value more than two times the estimated equation's standard error (2.64).

When the debt equation in table 2 is used to forecast GNP growth, there is a slight improvement in the absolute forecast errors. Relative to the 5.49 percent mean absolute error using $M 1$, using debt vields a mean absolute forecast enror of 5.11 percent. Three of the quarters' errors (V/1982, IIL/1982 and IV/1982) also exceed two times the debt regression's standard error $(2.79)$. The relatively minor improvement in the mean errors from using the debt measure disappears when RMSEs are compared. The RMSF derived from debt forecasts of GNP is 6.22 , somewhat larger than that from M1. Like the RMSE for M1, this value is more than twice the equation's standard error, again indicating little gain in the use of the debt measure over M1.

\section{GNP Forecasts Using Adjusted M1}

Based on the foregoing velocity comparisons and previous empirical fandings, it may prove useful to investigate the GNP forecasting record of M1 when the effects of the financial innovations are removed. To do this, M1 was replaced by adjusted Min in the regression equation and used to forecast GNP growth. ${ }^{19}$ The forecast results using the adjusted $M 1$ measure, also reported in table 4, corroborate the evidence based on comparing relative velocity movements. The GNP fore-

\footnotetext{
${ }^{19}$ The estimated equation is identical to the $M 1$ equation, except that a dummy variable term is added to capture the intercept shift in 1981 due to the introduction of NOW accounts on a nationwide basis. The cumulative effect of adjusted $\mathrm{M} 1$ (using the same lag structure as M1) is 1.21 , compared with 1.27 for $\mathrm{M} 1$. The $\overline{\mathrm{A}}^{2}$ for the equation using adjusted $\mathrm{M} 1$ is 0.56 , compared with 0.59 for $\mathrm{M} 1$.
}

cast errors from the adjusted-M1 equation are noticeably smaller than those for M1 of debt and, more important, are not continually one-sided. The consequence of this latter property is that the mean emor using adjusted M1 to forecast GNP growth is only 0.16 percent. Moreover, the mean absolute error is 2.95 percent, well below that for the other two measures. Finaly, the RMSE is calculated to be 3.33 , almost onehalf the value found using $M 1$ or debt to forecast GNP. ${ }^{20}$

The evidence indicates that the debt measure provides little or no improvement over M1 in forecasting GNP growth during the 1982-83 period. Moreover, us" ing a transactions definition of money that abstracts from the effects of recent financial innovations on M1 provides forecasts of GNP growth that are statistically superior to forecasts based on debt.

\section{SUMMARY AND CONCLUSION}

Some analysts have suggested that information from the liability side of the economy's balance sheet might be useful in the formation of monetary policy. In this paper, we have investigated this contention by comparing the relative abilities of M1 and total domestic nonfinancial debt to explain the growth of GNP. Based on evidence from the sample period 1960-81, M1 better explained movements in GNP than debt. Moreover, once the effects of M1 growth were accounted for ${ }^{2}$ debt growth did not significantly increase the explanatory power of the GNP equation. In contrast, M1 provided significant information to explain GNP growth, even after the effects of debt were included in the explanatory equation.

Out-of-sample forecast results of GNP during the 1982-83 period also indicate that there is no advantage to using the debt measure. Recent debt velocity behavior appears as equally at odds with historical patterns during post-trough periods as does M1 velocity behavior. What little improvement there is in using debt instead of $M 1$ to lorecast GNP stems from recent financial innovations which bloated the measured growth of $\mathrm{M1}$ in $1982-83$. When an M1 measure that adjusts for such effects is used, GNP growth rate forecasts based on the behavion of debt fare poorly compared with the adjusted M1 measure.

Thus, there is little evidence to support the use of a broad debt measure as yet another intermediate target variable for monetary policy.

\footnotetext{
${ }^{20}$ Judd and McElhattan, based on a different measure of adjusted M1, also find an improved forecasting record relative to the published $\mathrm{M} 1$ growth rate during $1982-83$.
} 


\section{REPERENCES}

Batten, Dallas S., and Daniel L. Thornton. "How Robust ane the Policy Conclusions of the St. Louis Equation?" this Review (June July 1984), pp. 26-32.

Carlson, Keith M., and Scott E. Hein. "Monetary Aggregates as Monetary Indicators," this Review (November 1980), pp. 12-21.

Davidson, Lawrence S., and R. W. Hafer. "Some Evidence on Selecting an Intermediate Target for Monetary Poticy," Southern Economic Journal (October 1983), pp. 406-21.

Friedman, Benjamin M. "The Relative Stability of Money and Credit 'Velocities' in the United States: Evidence and Some Specular tions," Working Paper No. 645 (National Bureau of Economic Research, 1981).

"Money, Credit and Nonfinancial Economic Activity: An Empirical Study of Five Countries," Working Paper No. 1033 (National Bureau of Economic Research, 1982).

"Monetary Policy with a Credit Aggregate Target," in Kanl Brunner and Allan H. Meltzer, eds., Money, Monetary Policy, and Financial Institutions, Carnegie-Rochester Conference Series on Public Policy, (Spring 1983a), pp. $117-48$.

"The Roles of Money and Credit in Macroeconomic Analysis," in James Tobin, ed., Macroeconomics, Prices, and Quantities: Essays in Memory of Arthur M. Okun (The Brookings Institution, 1983b), pp. $161-89$.

Friedman, Mitton, and David Meiselman. "The Relative Stability of Monetary Velocity and the Investment Multiplier in the United States 1897-1958," in the Commission on Money and Credit, Stabilization Policies (Prentice Hall, 1963), pp. 165-268.

Hater, R, W. "Selecting a Monetary Indicator; A Test of the New Monetary Aggregates," this Review (February 1981), pp. 12-18.

"The Role of Fiscal Policy in the St. Louis Equation," this Review (January 1982), pp. 17-22.

"Choosing Belween $\mathrm{M} 1$ and Debt as an Intermediate Target for Monetary Policy" (a paper presented at the CarnegieRochester Conference Series on Public Policy, April 13-14, 1984a).

"The Money-GNP Link: Assessing Aiternative Transaction Measures," this Review (March 1984b), pp. 19-27.

Hamburger, Michael J. "Indicators of Monetary Policy: The Argu- ments and the Evidence," American Economic Review, Papers and Proceedings (May 1970), pp. 32-39.

Hein, Scott $E_{.+}$and Paul T. W. M. Veugelers. "Predicting Velocity Growth: A Time Series Perspective," this Review (October 1983), pp. 34-43.

Judd, John P. "The Recent Decline in Velocity: Instability in Money Demand or Infiation?" Federal Reserve Bank of San Francisco Economic Review (Spring 1983), pp. 12-19.

Judd, John P., and Rose McElhattan. "The Behavior of Money and the Economy in 1982-83," Federal Reserve Bank of San Francisco Economic Review (Summer 1983), pp. 46-51.

Judd, John P., and Brian Motley. "M1 versus M2: Which is More Reliable? "Working Papers in Applied Economic Theory and Econometrics, No. 83-04 (Federal Reserve Bank of San Francisco, October 1983).

Kane, Edward J. "Selecting Monetary Targets in a Changing Financial Environment, " in Monetary Policy Issues in the 1980s, a symposium sponsored by the Federal Reserve Bank of Kansas City (August 9 and 10, 1982), pp. 181-206.

Kareken, J. M., T. Muench, and N. Wallace. "Optimal Open Market Strategy: The Use of Information Variables," American Economic Review (March 1973), pp. 156-72.

Kopcke, Richard W. "Must the Ideal 'Money Stock' be Controllable?" New England Economic Review (March/April 1983), pp. $10-23$.

Morris, Frank E. "Do the Monelary Aggregates Have a Future as Targets of Federal Reserve Policy?" New England Economic Review (March/April 1982), pp. 5-14.

"Monetarism without Money," New England Economic Review (March/April 1983), pp. 5-9.

Porter, Richard D., and Edward K. Offenbacher. "Empirical Comparisons of Credit and Monetary Aggregates Using Vector Autoregressive Methods, "Federal Reserve Bank of Richmond Economic Review (November/December 1983), pp. 16-29.

Spindt, Paul A. "Money is What Money Does: Monetary Aggregation and the Equation of Exchange," (Board of Governors of the Federal Reserve System, 1984; processed).

Tatom, John A. "Energy Prices and Short-Run Economic Pertor. mance," this Review (January 1981), pp. 3-17.

"Was the 1982 Velocity Decline Unusual?" this Review (August/September 1983), pp. $5-15$. 